\title{
THE
}

\section{Marine Growth and Morphometrics for Three Populations of Atlantic Salmon from Eastern Maine, USA}

Timothy F. Sheehan

John F. Kocik

Steven X. Cadrin

Christopher M. Legault

Ernest Atkinson

See next page for additional authors

Follow this and additional works at: https://digitalcommons.uri.edu/favs_facpubs

Terms of Use

All rights reserved under copyright.

\section{Citation/Publisher Attribution}

Sheehan , T. F., Kocik , J. F., Cadrin, S. X., Legault, C. M., Ernest Atkinson, E., \& Bengtson, D. A. (2005).

Marine Growth and Morphometrics for Three Populations of Atlantic Salmon from Eastern Maine, USA.

Transactions of the American Fisheries Society, 134(3), 775-788. doi: 10.1577/T04-067.1

Available at: http://dx.doi.org/10.1577/T04-067.1

This Article is brought to you for free and open access by the Fisheries, Animal and Veterinary Sciences at DigitalCommons@URI. It has been accepted for inclusion in Fisheries, Animal and Veterinary Sciences Faculty Publications by an authorized administrator of DigitalCommons@URI. For more information, please contact digitalcommons-group@uri.edu. 
Authors

Timothy F. Sheehan, John F. Kocik, Steven X. Cadrin, Christopher M. Legault, Ernest Atkinson, and David A. Bengtson

This article is available at DigitalCommons@URI: https://digitalcommons.uri.edu/favs_facpubs/6 
This article was downloaded by: [University Of Rhode Island]

On: 14 February 2013, At: 09:18

Publisher: Taylor \& Francis

Informa Ltd Registered in England and Wales Registered Number: 1072954 Registered office: Mortimer House, 37-41 Mortimer Street, London W1T 3J H, UK

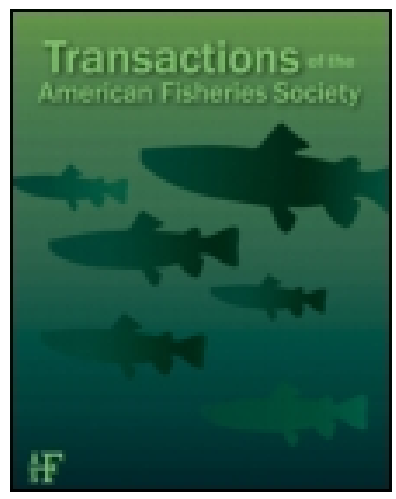

\section{Transactions of the American Fisheries Society}

Publication details, including instructions for authors and subscription information:

http:// www. tandfonline.com/loi/ utaf20

\section{Marine Growth and Morphometrics for Three Populations of Atlantic Salmon from Eastern Maine, USA}

Timothy F. Sheehan $^{a}$, J ohn F. Kocik ${ }^{a}$, Steven X. Cadrin ${ }^{a}$, Christopher M. Legault $^{\text {a }}$, Ernest Atkinson ${ }^{b} \&$ David Bengtson ${ }^{c}$

${ }^{a}$ National Marine Fisheries Service, Northeast Fisheries Science Center, 166 Water Street, Woods Hole, Massachusetts, 02543, USA

${ }^{b}$ Maine Atlantic Salmon Commission, Downeast Field Office, Post Office Box 178, J onesboro, Maine, 04648, USA

' University of Rhode Island, Department of Fisheries, Animal and Veterinary Science, Kingston, Rhode Island, 02881, USA

Version of record first published: 09 J an 2011.

To cite this article: Timothy F. Sheehan, J ohn F. Kocik, Steven X. Cadrin, Christopher M. Legault , Ernest Atkinson \& David Bengtson (2005): Marine Growth and Morphometrics for Three Populations of Atlantic Salmon from Eastern Maine, USA, Transactions of the American Fisheries Society, 134:3, 775-788

To link to this article: http:// dx.doi.org/ 10.1577/ T04-067.1

\section{PLEASE SCROLL DOWN FOR ARTICLE}

Full terms and conditions of use: http://www.tandfonline.com/page/terms-and-conditions

This article may be used for research, teaching, and private study purposes. Any substantial or systematic reproduction, redistribution, reselling, loan, sub-licensing, systematic supply, or distribution in any form to anyone is expressly forbidden.

The publisher does not give any warranty express or implied or make any representation that the contents will be complete or accurate or up to date. The accuracy of any instructions, formulae, and drug doses should be independently verified with primary sources. The publisher shall not be liable for any loss, actions, claims, proceedings, demand, or costs or damages whatsoever or howsoever caused arising directly or indirectly in connection with or arising out of the use of this material. 


\title{
Marine Growth and Morphometrics for Three Populations of Atlantic Salmon from Eastern Maine, USA
}

\author{
Timothy F. Sheehan,* John F. Kocik, Steven X. Cadrin, and \\ Christopher M. Legault \\ National Marine Fisheries Service, Northeast Fisheries Science Center, \\ 166 Water Street, Woods Hole, Massachusetts 02543, USA \\ ERNEST ATKINSON \\ Maine Atlantic Salmon Commission, Downeast Field Office, \\ Post Office Box 178, Jonesboro, Maine 04648, USA \\ DAVID BENGTSON \\ University of Rhode Island, Department of Fisheries, Animal and Veterinary Science, \\ Kingston, Rhode Island 02881, USA
}

\begin{abstract}
Significant differences in growth and prespawning body morphology were detected among three stocks of Atlantic salmon reared in a common marine environment. Smolts originating from river-specific broodstock of the Machias, East Machias, and Dennys populations were reared at two marine net-pen facilities for 25 months. Significant differences in stock-specific growth were observed among two stocks at both sites, suggesting a genetic basis for the observed phenotypic variation. There was a significant stock effect to the total measured phenotypic variation based on collected truss network analyses. Linear discriminant function analysis of a truss network of morphometric distances allowed for $73 \%$ accuracy of stock classification. A thin-plate spline procedure characterized the Machias body form as having a shortened narrow caudal peduncle region, a compressed body with an elongated trunk, and a deeper head region relative to the other two stocks. Phenotypic variation may be associated with hydrological characteristics of the Machias watershed.
\end{abstract}

In North America, Atlantic salmon Salmo salar historically ranged from the Housatonic River (Connecticut, USA) northward to the Leaves River (Quebec, Canada). Populations in the southern portion of the historical range have been extirpated and only eight naturally reproducing Atlantic salmon populations remain in the United States (Colligan et al. 1999). These eight populations are part of the Gulf of Maine Distinct Population Segment (DPS), which probably ranged from the Kennebec River to the outer Bay of Fundy (Colligan et al. 1999). These remnant populations have experienced declines in abundance significant enough to warrant being listed as an endangered species in 2000 (65 Federal Register 69459, November 17, 2000). From 2002 to 2003, returns to these populations were less than 100 for all eight populations (U.S. Atlantic Salmon Assessment Committee 2002).

Despite a substantial history of stocking (Baum

\footnotetext{
* Corresponding author: tim.sheehan@ noaa.gov
}

Received April 28, 2004; accepted November 20, 2004 Published online May 17, 2005
1997), evaluation of past stocking efforts suggests they have been of limited success (Fletcher et al. 1982; King et al. 2001). Studies of the genetic structure of these populations relative to neighboring Canadian populations indicate that Maine's Atlantic salmon populations are genetically distinct from the Canadian populations and display statistical differentiation among populations; moreover, these Maine populations exhibit the genetic structure expected in wild populations with similar geographical ranges (King et al. 2000; National Research Council 2002). It is unlikely that the remnant populations exist in their pure native form, but their persistence over time in their indigenous habitat suggests that important heritable adaptations probably still exist (Colligan et al. 1999).

Ihssen et al. (1981) defined a stock as an intraspecific group of randomly mating individuals with temporal or spatial integrity. Discrete salmon stocks are maintained by natural selection and precise homing (Ricker 1972; MacLean and Evans 1981). Maine Atlantic salmon return to their natal river to spawn with high fidelity (estimated stray- 
ing rates, $<1-2 \%$; Baum 1997). Hence, a river is expected to contain at least one but potentially multiple salmon stocks, depending on mesohabitat conditions (Saunders 1981). This stock delineation is expressed as differences with respect to anatomical (Nyman and Pippy 1972; Swain and Holtby 1989), morphological (Baum and Meister 1971; Ritter 1975; Swain and Holtby 1989), and behavioral (Schaffer and Elson 1975; Taylor and McPhail 1985b; Swain and Holtby 1989) features. Differences in these features are thought to underlie stock-specific differences driven by local environments (Verspoor 1997; Hansen and Quinn 1998).

Numerous investigators have examined the genetic composition of Atlantic salmon stocks (Verspoor 1986; Davidson et al. 1989; Nielsen 1998; King et al. 2000, 2001) and shown that specific, genetically based traits are essential to the survival of many of these populations (MacLean et al. 1981; Taylor 1991; Primmer et al. 2003). However, the linkage between these subtle genetic differences and their corresponding adaptive characteristics, as expressed by morphological or behavioral differences between and among stocks, has rarely been examined for Atlantic salmon (Ihssen et al. 1981; Nielsen 1998). A better understanding of what these subtle genetic differences between populations mean relative to biology is important to informed decision making.

An alternative approach to detecting genetic differences among populations is to investigate the genetic and environmental interactions that affect phenotypic expression. In this approach, genetic diversity among populations is assessed in different populations reared in a common environment (Riddell et al. 1981; Taylor and McPhail 1985a, 1985b; Swain and Holtby 1989). Phenotypic variation observed between different strains of fish reared in a common environment is primarily due to heritability of genetic factors (Tave 1986). These types of tests are most effective when the populations studied have experienced extreme selection pressures or large population declines (Ihssen et al. 1981), as Maine Atlantic salmon have (Colligan et al. 1999).

We evaluated differences in marine growth of three Maine Atlantic salmon stocks originating from river-specific broodstock populations of the Dennys, East Machias, and Machias rivers. The three stocks were raised in a common net-pen environment, thereby minimizing any environmentally induced variation in growth. Although differences in some morphometric and meristic char- acters had been previously observed (Kincaid et al. 1994), these differences could not be partitioned into environmental and genetic components. We will test the hypothesis that there may be detectable differences in the marine growth and prespawning body morphometrics after being reared within a common marine environment. These studies may allow researchers to gain insights into potential adaptive characteristics resulting from different stock-specific selective pressures. The insights gained should aid managers as they develop conservation and restoration management plans for each population and the DPS collectively.

\section{Methods}

Rearing history.-In 1992, the U.S. Fish and Wildlife Service (USFWS) adopted a policy of river-specific stocking as a tool for conserving the genetic diversity of the remnant Atlantic salmon populations in Maine. Naturally reared parr are collected annually and raised to maturity at the USFWS's Craig Brook National Fish Hatchery (CBNFH; a multiple broodstock/fry production facility). The parr collections were designed to maximize the spatial coverage for each river and to assure that all natural matings would be well represented in the incoming broodstock by sampling near documented redds. After collection, broodstock are maintained and reared to maturity within CBNFH under similar conditions for 2-3 spawning events over the course of a 4-5-year period postcollection. Both broodstock and their progeny are reared in a river-specific fashion (remaining isolated according to river of origin during their hatchery existence), and the progeny ultimately are stocked back into the donor river (i.e., progeny of Machias-origin fish stocked into the Machias River, and so forth).

In November 1996, USFWS spawned Dennys (DE), East Machias (EM), and Machias (MC) populations (Figures 1,2) at CBNFH over a 21-d period. In all crossings one female was fertilized by one male. In February 1997, USFWS staff at CBNFH transferred approximately 60,000 eyedembryos (approximately 20,000/stock) to two private aquaculture facilities owned by Atlantic Salmon of Maine Ltd. (Figure 2). For rearing continuity, the aquaculture industry requested that only embryos at a developmental stage equivalent to concurrent commercial production be transferred. Because of this, not all crosses were represented, but all available year-classes were; USFWS transferred aliquots of the embryos of 62 


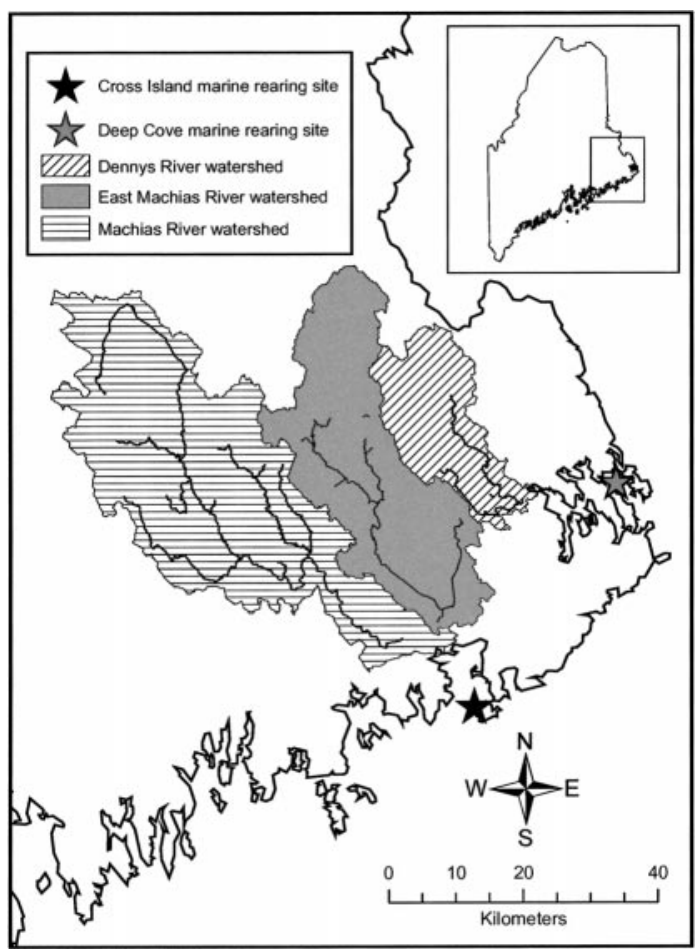

FIGURE 1.- The area of interest detailing the three watersheds and two marine net-pen facility locations utilized in this study.

of 85 Dennys River females (73\%), 64 of 93 East Machias females (69\%), and 71 of 96 Machias females $(74 \%)$. The DE and EM embryos were transferred to the Solon facility (Skowhegan, Maine); because of logistical constraints, the MC embryos were transferred to the Oquossoc facility (Rangley, Maine; Tom King, USFWS, CBNFH, personal communication). At both sites, the fish were reared according to standard Atlantic salmon commercial aquaculture procedures, the details of which are protected under corporate privacy procedures (Atlantic Salmon of Maine, Ltd.). However, considering that one company owned both facilities, the protocols were similar at both sites; the main difference was the water source, as the Oquossoc facility is characterized as having cooler water temperatures than the Solon facility.

In March 1998, all reared salmon at both facilities were adipose fin-clipped and sorted into two size categories: $1+$ parr and $1+$ smolt. A random sample of 2,000 1+ smolts per stock $(6,0001+$ smolts overall) was obtained. Each fish was tagged with two Visual Implant Elastomer tags (VIE; Northwest Marine Technology, Inc.): one in the right adipose eye tissue and the other in the right

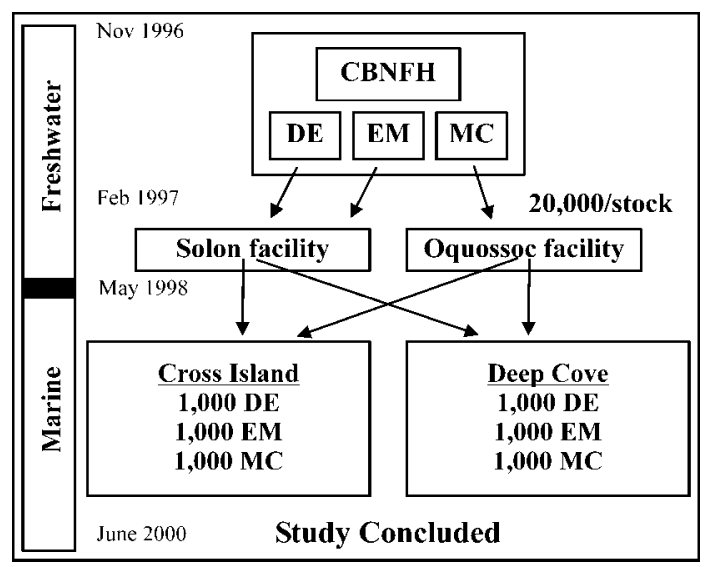

FIGURE 2.-Timeline detailing the major events undertaken throughout the study. Details concerning the location, environment, stock, and numbers of individuals are provided.

lower jaw. Each stock was tagged with a unique color (FitzGerald et al. 2004). In May 1998, each lot of the double-marked smolts was randomly divided into two and transferred to one of two commercial net-pen facilities for marine rearing (Figure 2). One net-pen was located at Cross Island (CI; owned and operated by Atlantic Salmon of Maine Ltd.), Machias Bay, Maine; the other netpen was located at Deep Cove (DC; owned and operated by Connors Brothers Aquaculture), Cobscook Bay, Maine (Figure 1). As such, each pen received 1,000 fish of each stock for a total of 3,000 fish per site per pen.

The fish remained in the marine netpens through two full sea-winters (from May 1998 through October 2000). During this period, the fish were reared according to standard commercial Atlantic salmon aquaculture protocols (Atlantic Salmon of Maine Ltd. and Connors Brothers Aquaculture), except that the density of fish in each cage $(3,000$ smolts per cage) was markedly lower than in standard production $(32,000$ smolts per cage). We monitored marine growth for 25 months and sampling concluded in June 2000 (Figure 2). In October 2000, individuals from the Cross Island facility were stocked as 2-sea-winter mature adults into four rivers in Maine. The Dennys, East Machias and Machias Rivers were stocked in a riverspecific fashion while the St Croix (a U.S.-Canadian transboundary river, not protected under the Endangered Species Act) received mixed origin adults. Disease concerns prevented fish reared at the Deep Cove site from being stocked, and Con- 


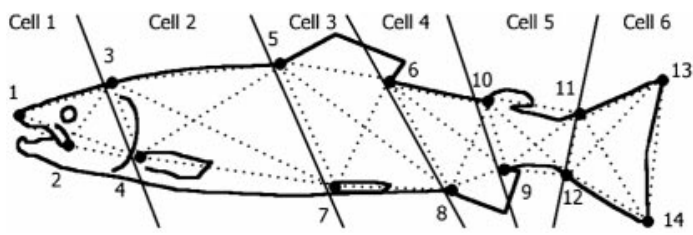

FIGURE 3.-Truss network of morphometric characters identifying the 14 landmark locations (solid circles), 31 distances (dashed lines), and 6 corresponding cells (delineated by solid lines) or regions of the body used in this study.

nors Brothers Aquaculture subsequently harvested these salmon in July 2000.

Sampling.-During the 25-month study, the fish were sampled on 13 occasions. Sampling was started in May 1998, just before the smolts weretransferred to the marine net-pens, and the last sample was taken in June 2000. At each net-pen facility, mean hourly water temperatures were recorded.

During each sampling, salmon were seined to the surface of the holding facility and individual fish were randomly dip-netted from the seined animals. We anesthetized fish by immersion in a tricaine methanesulfonate solution and determined stock origin by examining the VIE tag. We then measured and recorded total length $(\mathrm{mm})$ and total weight $(\mathrm{g})$. Each individual was returned to the net-pen, but outside of the seined area, to avoid recapture. We targeted at least 30 individuals per stock per site during each sampling event and at least 50 per stock per site taken in the initial and final samples.

During July 2000, a sample (109 fish) of the salmon harvested at the DC site was photographed at the Connors Brothers Processing Plant in Eastport, Maine. Each fish was identified to stock by VIE examination and photographed on a standard fish measuring board, left side up, using a $35-\mathrm{mm}$ camera mounted on a tripod approximately 120 $\mathrm{cm}$ above the fish.

The photographs were developed electronically and stored in jpg format. A truss network of morphometric characters (Strauss and Bookstein 1982) was obtained from the 109 images (DE 40, EM 29 , and MC 40, with approximately equal sex ratios for all stocks). Fourteen landmark coordinates were located per specimen as described by Winans (1984) for Pacific salmon. From these landmarks, 31 morphometric characters (distances) were calculated from six regions (network cells) of the body (Strauss and Bookstein 1982; Figure 3). To remove the effect of fish size from these data, we applied Burnaby's size correction method (Burnaby 1966; Rohlf and Bookstein 1987). This correction method removes the isometric growth-related variation by performing a principle components analysis (PCA) of the raw data, setting the first principle component scores to zero, and then reversing the PCA process, back-transforming the principle component scores to a size-free data set so that patterns in allometric growth variation (i.e., shape) among the populations could be detected.

Length-weight analyses.-A one-way analysis of variance (ANOVA) was performed on the length data measurements taken when the smolts were transferred to the marine net-pen in May 1998 to evaluate any differences in length among the three stocks at the onset of the study. For each subsequent sampling event, chi-square analyses were performed on site- and stock-specific capture frequencies to test for stock-specific differences in survival ( 25 total: 13 for DC and 12 for $\mathrm{CI}$ ). Chisquare analyses were also performed on the siteand stock-specific frequencies of extreme body shape relative to a fixed, a priori standard (22 total: 13 for DC and 9 for $\mathrm{CI}$ ). Extreme body shapes were those that fell outside of the $95 \%$ body shape confidence interval based on length and weight from 1,245 adult salmon returns in the 1987-1988 Penobscot River run (data from Figure 8b in Baum 1997). This analysis was performed to test for stock-specific differences in the rate of extreme body shape development; however, no individuals were excluded from subsequent analyses as a result of this test. Differences in growth rates were tested by using a factorial design ANOVA on the siteand stock-specific length data collected over the course of the study. To test for differences in length-weight relationships among the three stocks, we performed analysis of covariances (ANCOVA) on the natural log of the site- and stock-specific length and weight data obtained during this study. A factorial design ANOVA was conducted on the length data from the final sampling in June 2000 to partition the observed phenotypic variation $\left(V_{P}\right)$ into its three components: $V_{E}$ (site effect), $V_{G}$ (stock effect), and $V_{G E}$ (sitestock interaction effect).

Morphometric analyses.-Multivariate ANOVA (MANOVA) was performed on the size-corrected morphometric data to test for stock-specific differences. We used Pillai's trace statistic because it is robust to moderate departures from MANOVA assumptions. Linear discriminant function analysis (LDF) was used to define the level of stock differentiation possible, based on the collected 
TABLE 1.- Sampling schedule and numbers of samples obtained from each rearing facility during the study by site, stock, and sampling event. In May 1998, before smolts were distributed to marine rearing facilities, 50 fish of each population were sampled. Abbreviations are as follows: DE = Dennys, EM = East Machias, and MC = Machias.

\begin{tabular}{|c|c|c|c|c|c|c|c|c|}
\hline \multirow[b]{2}{*}{ Date } & \multicolumn{4}{|c|}{ Cross Island } & \multicolumn{4}{|c|}{ Deep Cove } \\
\hline & DE & EM & MC & Total & DE & EM & $\mathrm{MC}$ & Total \\
\hline \multicolumn{9}{|l|}{1998} \\
\hline Jun & 31 & 33 & 30 & 94 & 33 & 30 & 30 & 93 \\
\hline Jul & 30 & 31 & 31 & 92 & 33 & 30 & 32 & 95 \\
\hline $\mathrm{Oct}^{\mathrm{a}}$ & 16 & 14 & 16 & 46 & 31 & 31 & 33 & 95 \\
\hline $\mathrm{Nov}^{\mathrm{a}}$ & 23 & 30 & 35 & 88 & 35 & 34 & 35 & 104 \\
\hline \multicolumn{9}{|l|}{1999} \\
\hline Apr & 35 & 34 & 44 & 113 & 35 & 35 & 43 & 113 \\
\hline May & 37 & 36 & 30 & 103 & 39 & 35 & 35 & 109 \\
\hline Jun & 39 & 35 & 33 & 107 & 34 & 39 & 36 & 109 \\
\hline Jul & 38 & 38 & 33 & 109 & 38 & 34 & 37 & 109 \\
\hline Aug & 45 & 43 & 36 & 124 & 50 & 49 & 40 & 139 \\
\hline Oct $^{\mathrm{a}}$ & 10 & & & 10 & 38 & 36 & 27 & 101 \\
\hline Nov & & & & & 41 & 44 & 34 & 119 \\
\hline \multicolumn{9}{|l|}{2000} \\
\hline Jun & 78 & 82 & 65 & 225 & 50 & 60 & 42 & 152 \\
\hline Totals & 382 & 376 & 353 & 1,111 & 457 & 457 & 424 & 1,338 \\
\hline
\end{tabular}

${ }^{a}$ Weights were not obtained from the Cross Island facility due to equipment failure.

morphometric dataset. The grouping variable was stock, and all 31 size-corrected morphometric distances were incorporated into the function. All three stocks were included in the morphometric analysis.

A cross-validation classification matrix (i.e., each observation was removed from the LDF analysis and classified as an extrinsic observation) was generated to evaluate the classification power of the discriminant function. These same LDF procedures were then repeated on different data combinations and on the cell-specific measurement datasets.

Thin-plate spline (TPS) procedures (Bookstein 1991) were used on the landmark data to graphically evaluate the relative warping in body shape needed to represent the various extremes detected from the LDF. TPS (Rohlf 2001) was used to measure the bending energy (expressed as partial warps) needed to transform the measured landmarks of one specimen relative to a reference specimen (Rohlf and Marcus 1983; Cadrin 2000). The partial warps were then displayed graphically; if the body morphometrics for two specimens compared by TPS procedures were identical, the output grid would contain only straight lines, the elements of which would intersect only at $90^{\circ}$ angles. The warping of the gridlines within a TPS plot, both in direction and magnitude, is directly related to the localized energy needed to bend one form to fit the dimensions outlined from the reference form. An alternative approach for generating a classification matrix would have been to use TPS procedures to obtain partial warps for input into LDF procedures. We did not use this approach because partial warps have been described as being "biologically arbitrary" and their biological interpretation has been strongly criticized (Cadrin 2000).

\section{Results}

\section{Sampling}

Nearly 2,600 length measurements were obtained during 24 sampling events (Table 1). We had 11 sample events (1,111 length measurements) at the CI site (the November 1999 and the October 1999 samples were cancelled or terminated early because of water temperature or fish health concerns) and 12 sample events (1,338 length measurements) from the DC site. During freshwater sampling in May 1998, just before the smolts were distributed to the marine rearing sites, we sampled 50 fish per population (150 total fish). Fish at both rearing facilities experienced a wide range of temperatures. In general, water temperatures at the CI site were both warmer in the winter and cooler in the summer than at the DC site and resulted in a better growth environment.

\section{Length-Weight Relationships}

Significant differences in mean length were detected among the three stocks before the marine transfer (Figure 4a) as indicated by an ANOVA on length $(P<0.001)$. A Tukey's pairwise comparison revealed that MC-origin fish were significantly shorter than the DE and EM fish (Figure 


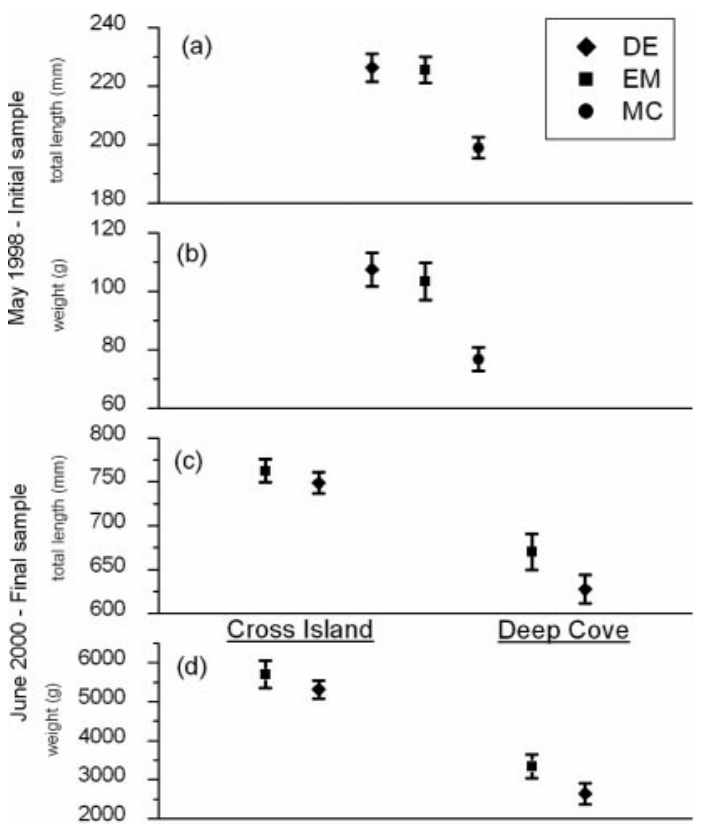

FIGURE 4.-Stock-specific initial (May 1998) average (a) lengths and (b) weights and stock and site-specific final (June 2000) (c) lengths and (d) weights with corresponding $95 \%$ confidence intervals

4a). A Kruskal-Wallis one-way ANOVA on ranks for the initial weight data yielded similar results $(P<0.001$; Figure $4 b)$. MC fish were therefore removed from all subsequent length-weight analyses because the disparity in initial size could not be adjusted. However, the MC fish were included in comparisons of length-weight parameters because there was sufficient overlap in length-weight data with those for the DE and EM stocks (Figure 5) throughout the study.

The average length of DE fish was significantly greater than those of EM fish at both marine sites at the end of the study ( $P=0.0003$; Table 2, Figure $4 c)$. Similar results were obtained in weight comparisons $(P=0.0003$; Figure $4 \mathrm{~d})$. These differences did not result from a subset of the fish within a stock growing faster at any point during the study, but rather from an overall increase in mean length across all individuals sampled (Figure 6). The CI fish attained a larger average size across all stocks (Figures $4 \mathrm{c}-\mathrm{d}$ ), resulting in a reduced final interpopulation length difference: CI difference $(13.9 \mathrm{~mm})$ versus DC difference $(42.7 \mathrm{~mm})$. No stock-specific differences in survival were detected at either marine site (chi-square analyses: 24 not significant and 1 significant at the $P=0.05$ level). In addition, no differences in the ratios of extreme body shapes were detected at either site (chi-square analyses: 21 not significant and 1 significant at the $P=0.05$ level). At the DC site, DE and EM fish grew at different rates (stock-sampling event, $P=0.0073$ ) over the course of the study; at the CI site, in contrast, the growth rates of the two stocks were not statistically different $(P=0.3463)$. No patterning was evident in the instantaneous growth rates observed over the course of the study. No significant differences were detected in slope coefficients of the overall stock-specific length-weight regressions at either site (DC $P=0.132$ and CI $P=0.081$; Figure 7). Although sampling-event-specific comparisons revealed some significant differences, no temporal patterns were discernable. Our results indicate that growth of the stocks did not differ significantly from each other with respect to the relationship between length and weight; rather, the stocks grew at different rates.

The total phenotypic variation observed was partitioned into its four components via the site and stock factorial ANOVA (Table 2). A significant proportion of this variation $(40.1 \%)$ was attributable to environmental effects (site effect $P$ $<0.0001$ ). A significant genetic effect (stock effect $P=0.0003$ ) accounted for $2.8 \%$ of the variation. The genetic-environmental interaction was nonsignificant at the $\alpha=0.05$ level (site-stock interaction $P=0.0653$ ) and accounted for only a small proportion of the total variation $(0.7 \%)$. The remaining $56.4 \%$ of the variation is attributable to between-individual variation.

\section{Morphometric Results}

We detected a significant shape difference between the three populations of Atlantic salmon (Pillai's trace statistic $=1.241, \mathrm{df}=62,154, P<$ $0.0001)$. The overall LDF cross-validation classification accuracy for the three-way comparison was $73 \%$. Individuals of MC origin were the most distinct in terms of body morphometrics and thus had the highest cross-validation classification accuracy $(85 \%)$, followed by the DE and EM stocks (73\% and 59\%, respectively; Table 3). When the EM and DE datasets were combined and compared with that for the MC fish, the cross-validation classification accuracy increased to $90 \%$, providing further evidence of the morphological differentiation of the MC population. When only DE versus EM individuals were compared, the overall accuracy declined to $59 \%$ and no significant difference was detected (Pillai's trace statistic $=0.574$ with $\mathrm{df}=31,374, P<0.0829)$. 


\section{Cross Island}
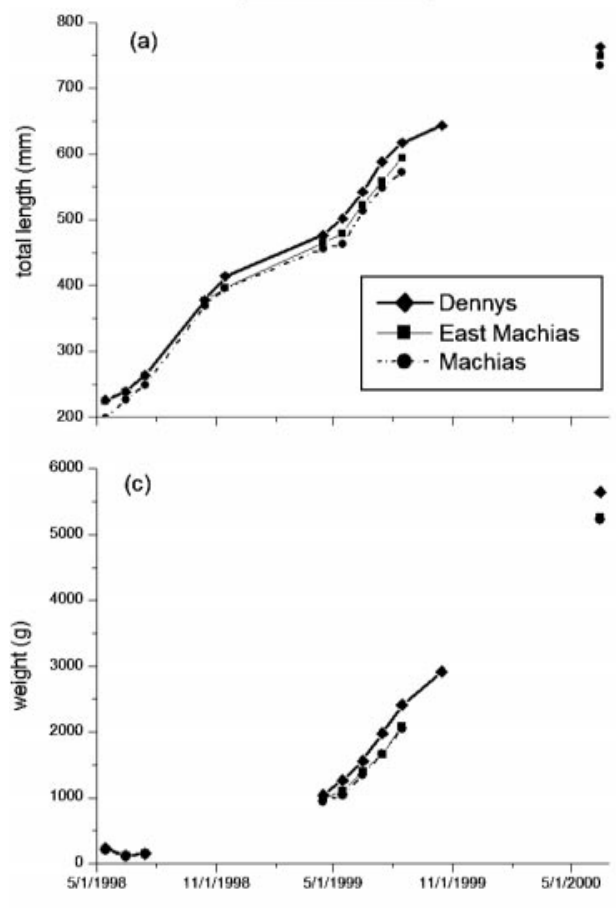

!

(b)

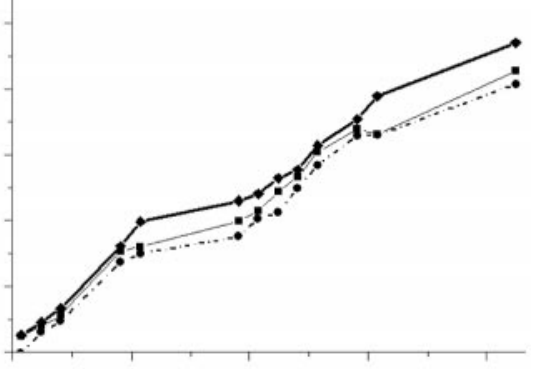

(d)

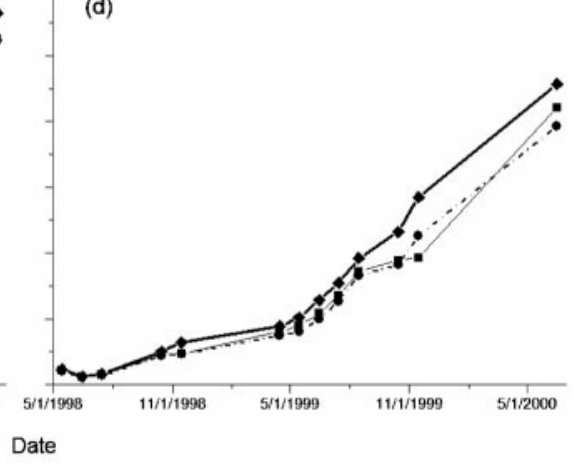

FIGURE 5.-Stock-specific average length in millimeters for (a) Cross Island and (b) Deep Cove fish and average weight in grams for (c) Cross Island and (d) Deep Cove.

A canonical score plot (Figure 8) developed from the LDF indicated that MC fish were separated from EM and DE fish along the primary axis, whereas EM fish were separated from DE fish along the secondary axis. Because Burnaby's size correction was performed on the raw truss distances, the primary axis represents allometric growth variation (i.e., shape) and is therefore not affected by specimen size. Approximately $83 \%$ of the variance was explained by the first canonical function.

Significant differences were detected between all six cell-specific datasets (Pillai's trace statistic of $P<0.05$ ), indicating higher degrees of clas- sification accuracies than expected by chance for each corresponding LDF. In all cases except cells 2 and 4, the MC fish were most distinct in terms of body shape and therefore had the highest crossvalidation classification accuracy. Overall, the highest cell-specific classification accuracies were associated with the head (cell 1), peduncle (cell 5), and caudal regions (cell 6; Table 3; Figure 3).

The canonical factor 1 TPS results indicate that MC fish have a deeper head region, more compressed bodies with elongated trunks, and a shortened narrow caudal peduncle compared with either DE or EM individuals (Figure 9a). When the opposite comparison is made (Figure 9b), the reverse

TABLE 2.- June 2000 (final) length data analysis of variance results for the Dennys and East Machias stocks only. Site and stock were designated as main effects, and a site-stock interaction term was included. Results are used for partitioning the total phenotypic variation (in length) into its three components: $V_{E}$ (environmental effect $=$ site). $V_{G}$ (genetic effect $=$ stock) and $V_{G E}($ environmental-genetic interaction effect $=$ site-stock interaction $)$.

\begin{tabular}{lrrrr}
\hline \multicolumn{1}{c}{ Variable } & df & Mean square & $F$-value & $P$-value \\
\hline Site effect & 1 & $742,769.1$ & 188.99 & $<0.0001$ \\
Stock effect & 1 & $51,884.9$ & 13.20 & 0.0003 \\
Site $\times$ stock interaction & 1 & $13,467.0$ & 3.43 & 0.0653 \\
Residual & 266 & $3,930.2$ & & \\
\hline
\end{tabular}




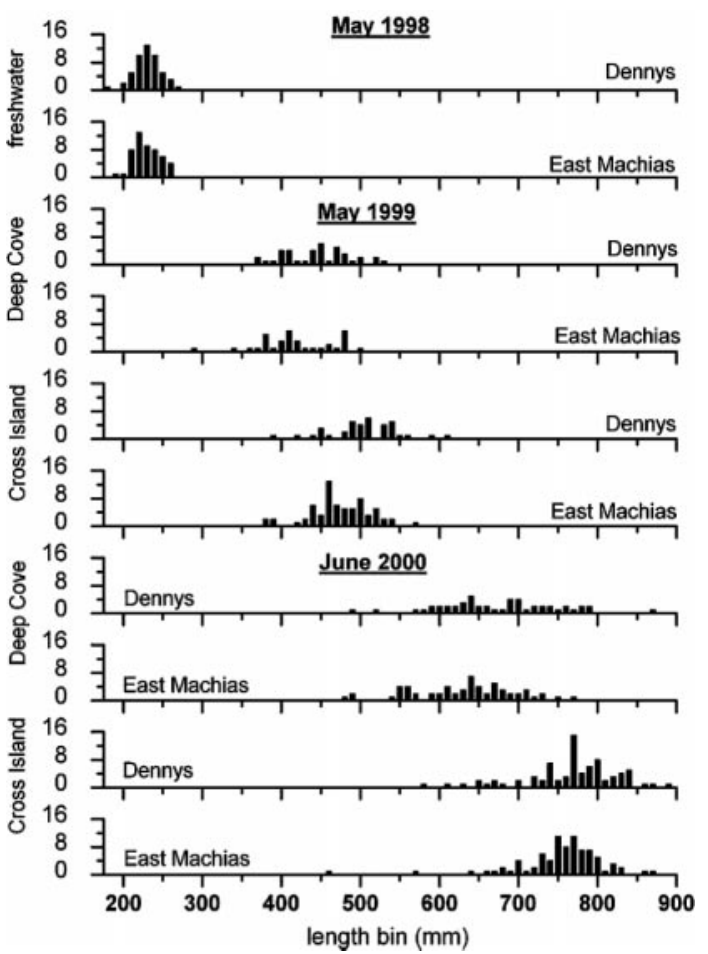

Figure 6.-Dennys and East Machias length frequencies by $10-\mathrm{mm}$ bins at the onset (May 1998), approximately halfway through (May 1999), and at the conclusion (June 2000) of the study.
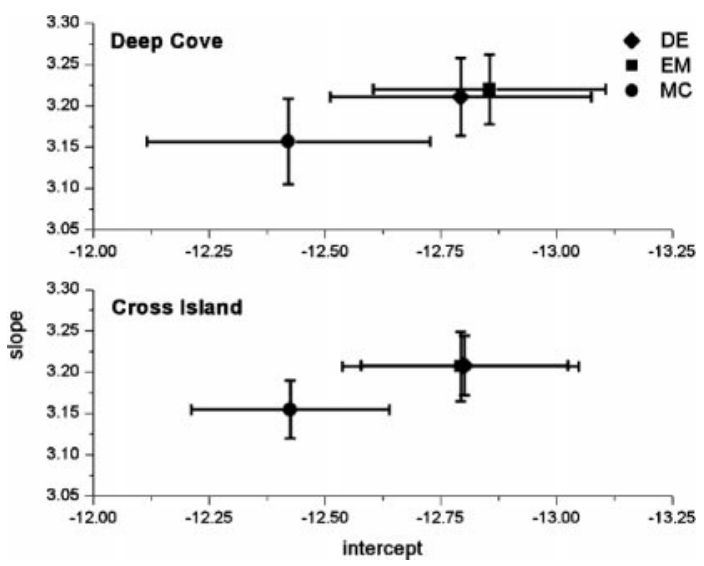

FIGURE 7.-Stock-specific length-weight regression parameters (data from May 1998 to June 2000) with corresponding $95 \%$ confidence intervals for each marine facility.
TABLE 3.-Cross-validation classification accuracy matrices for the overall and cell-specific linear discriminant functions (LDF). Columns represent LDF-assigned origin while rows indicate true origin and percent correctly classified to true origin by the LDF. Bold italics indicate fish correctly identified as to origin and overall and cell-specific total percent correctly identified. Abbreviations are as follows: $\mathrm{DE}=$ Dennys, $\mathrm{EM}=$ East Machias, and $\mathrm{MC}=$ Machias.

\begin{tabular}{|c|c|c|c|c|}
\hline & DE & EM & MC & $\begin{array}{l}\text { Percent } \\
\text { correct }\end{array}$ \\
\hline \multicolumn{5}{|c|}{ All Cells } \\
\hline DE & 29 & 10 & 1 & 73 \\
\hline EM & 9 & 17 & 3 & 59 \\
\hline $\mathrm{MC}$ & 1 & 5 & 34 & 85 \\
\hline All & 39 & 32 & 38 & 73 \\
\hline \multicolumn{5}{|c|}{ Cell 1} \\
\hline DE & 25 & 12 & 3 & 63 \\
\hline EM & 11 & 10 & 8 & 34 \\
\hline $\mathrm{MC}$ & 3 & 6 & 31 & 78 \\
\hline All & 39 & 28 & 42 & 61 \\
\hline \multicolumn{5}{|c|}{ Cell 2} \\
\hline DE & 23 & 11 & 6 & 58 \\
\hline EM & 10 & 12 & 7 & 41 \\
\hline $\mathrm{MC}$ & 9 & 10 & 21 & 53 \\
\hline All & 42 & 33 & 34 & 51 \\
\hline \multicolumn{5}{|c|}{ Cell 3} \\
\hline DE & 19 & 11 & 10 & 48 \\
\hline EM & 10 & 14 & 5 & 48 \\
\hline $\mathrm{MC}$ & 10 & 8 & 22 & 55 \\
\hline All & 39 & 33 & 37 & 50 \\
\hline \multicolumn{5}{|c|}{ Cell 4} \\
\hline $\mathrm{DE}$ & 14 & 12 & 14 & 35 \\
\hline EM & 6 & 15 & 8 & 52 \\
\hline $\mathrm{MC}$ & 11 & 9 & 20 & 50 \\
\hline All & 31 & 36 & 42 & 45 \\
\hline \multicolumn{5}{|c|}{ Cell 5} \\
\hline DE & 28 & 9 & 3 & 70 \\
\hline EM & 10 & 14 & 5 & 48 \\
\hline $\mathrm{MC}$ & 1 & 5 & 34 & 85 \\
\hline All & 39 & 28 & 42 & 70 \\
\hline \multicolumn{5}{|c|}{ Cell 6} \\
\hline DE & 25 & 10 & 5 & 63 \\
\hline EM & 9 & 15 & 5 & 52 \\
\hline $\mathrm{MC}$ & 2 & 5 & 33 & 83 \\
\hline All & 36 & 30 & 43 & 67 \\
\hline
\end{tabular}

is evident (compressed head, shortened and wider trunk region, and longer and narrower peduncle region). From the LDF results, significant morphological variation between the DE and EM stocks was not expected (i.e., segregation along canonical factor 2). The discriminating power between these two stocks is lower than with the MC fish, as indicated by the DE versus EM crossvalidation results (59\%) and the moderate degree of overlap for these two stocks along the canonical factor 2 axis (Figure 8). TPS procedures detected 


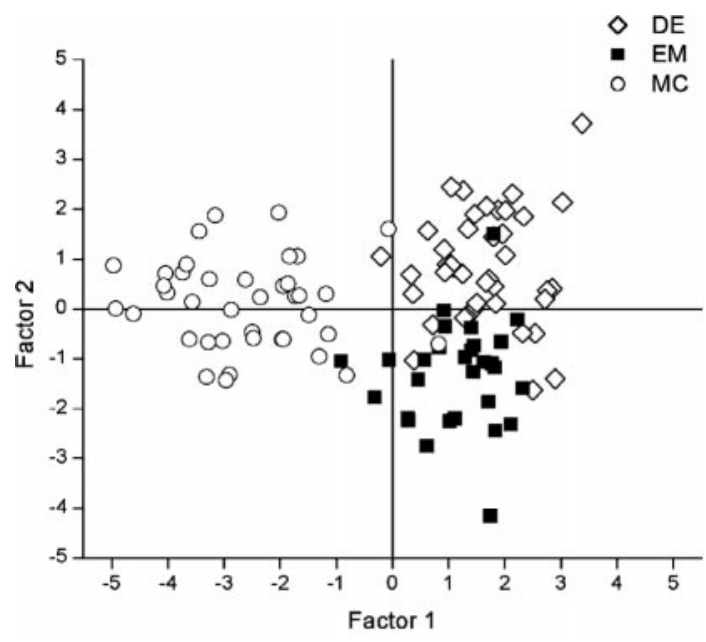

FIGURE 8.-Plot of canonical scores representing our three-stock, 31 size-corrected distance linear discriminant function. The Machias stock is segregated from the Dennys and East Machias along the Factor 1 axis, which accounts for approximately $83 \%$ of the total variation observed within the collected morphometric dataset.

little morphological variation within these two populations (Figures 9c-d).

\section{Discussion}

Atlantic salmon originating from Dennys, East Machias, and Machias rivers differed in terms of marine growth rates and prespawning body morphology, when reared in a common marine environment. An assessment of the genetic composition of many Atlantic salmon populations throughout this range found a significant amount of heterogeneity of haplotype frequencies within and among all classification levels of the species' present-day range: continental, country, and river (King et al. 2000). A recent National Academy of Science Review Board concurred with these findings and stated that there is considerable genetic divergence among Maine's eight protected populations (National Research Council 2002). Our study reinforces these conclusions; the results provide insight on phenotypic expression while suggesting that these subtle genetic differences may have biological/ecological significance for these populations.

The results show that DE-origin fish attained a significantly larger mean total length and weight than the EM-origin fish at both rearing sites. Differences between stocks were manifest in growth rate of fish during some component of the marine phase of their life cycle, but not as differences in (a)

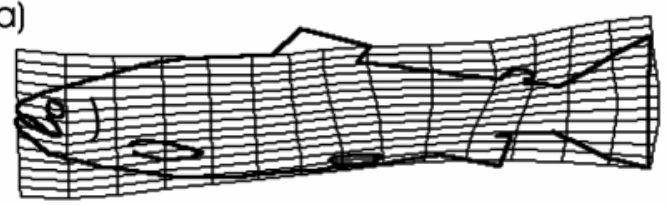

(b)

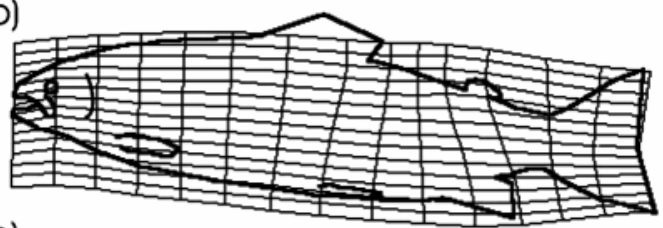

(c)

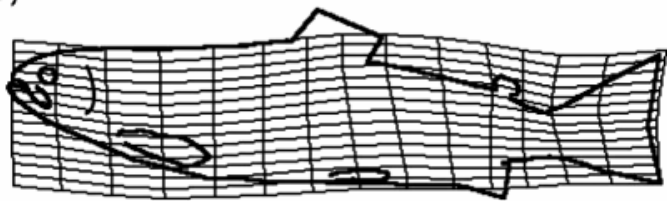

(d)

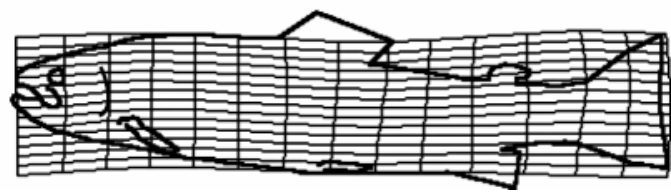

FIGURE 9.-Thin-plate spline output qualifying the partial warping necessary to contort the body of an individual to mirror a reference body type: (a) the bending energy necessary to warp a high Factor 1 body type (DE or EM) into a MC body type (low Factor 1), (b) a MC body type relative to a high Factor 1 body type (DE or EM), (c) a DE body relative to an EM body type, and (d) an EM body type relative to a DE body type.

survival, growth equation parameters, or ratios of extreme body shape. Given that growth in Atlantic salmon is a heritable trait (e.g., Refstie and Steine 1978; Thorpe and Mitchell 1981; Nicieza et al. 1994), these results suggest that the DE and EM stocks have inherently different growth potentials. These differences could be a result of inherent differences in marine growth dynamics or possibly of variation in each population's response to captive marine rearing. As such, given the common environmental influences experienced by the two stocks, even results related to behavior difference would have a genetic component.

The growth response for the two populations at each site was parallel. The accelerated rate at CI compared with that at DC, reflecting differing environmental conditions and husbandry protocols between the two sites, may have dampened differences between populations: Mean length differences between populations were only $1 / 3$ as great $(14 \mathrm{~mm}$ at $\mathrm{DC}$ versus $43 \mathrm{~mm}$ at $\mathrm{CI})$. The 
strong differences between the two sites make the resulting expression of phenotypic differences more compelling because these differences were maintained at both sites despite the fact that the CI fish were nearly double the weight of the DC fish.

Whether these growth differences are realized in the wild is uncertain because of the lack of adult trapping facilities on the three rivers (U.S. Atlantic Salmon Assessment Committee 2002) and the paucity of knowledge concerning marine migration patterns and the habitats utilized by these stocks (Taylor 1991; Conover 1998). Morphometric divergence for salmonids in captivity from their naturally reared conspecifics has been shown. The differences detected are qualitatively similar, but less, and may be related to the time spent in captivity (Flemming et al. 1994; Hard et al. 2000). Therefore the results from the current study may be somewhat conservative in terms of the extent of morphological differences detected. Additional investigations that mimic the natural environments for these populations are needed (1) to ascertain whether these phenotypic expressions would be realized in the wild and (2) to measure the rate and magnitude of their occurrence.

The significant variation in body form of the Machias fish compared to East Machias or Dennys fish (Figure 9a-b may have ecological underpinnings related to the topography of their home river. The importance of body and fin shape in relation to localized hydrological conditions has been well documented in numerous salmonid species (see Taylor 1991 and Cadrin 2000 for reviews). Local flow regimes are often the functional link between the selective forces driving local adaptations and certain salmonid body designs that may be more adapted for different life-history types (Carl and Healey 1984; Swain and Holtby 1989), river sizes (Hendry and Quinn 1997; Kinnison et al. 1998) and flow conditions (Riddell et al. 1981; Riddell and Leggett 1981; Taylor and McPhail 1985a, 1985b). As such, we hypothesize that the body shape of prespawning Machias-origin fish may have evolved in response to selective pressures within the Machias watershed.

Machias is a Native American word meaning "bad little falls" (Fletcher et al. 1982). The Bad Little Falls area is the lowermost section of Machias River; this 213-m-long gorge is characterized by nine cascading pools that drop approximately $15 \mathrm{~m}$ before emptying into upper Machias Bay. There is no suitable Atlantic salmon spawning habitat below the gorge, and this section of river thus appears to be a formidable obstacle for a prespawning migratory adult Atlantic salmon to ascend en route to the spawning grounds. The precipitous nature of the Machias Gorge limits upstream migration of weaker swimming anadromous species, such as alewives Alosa pseudoharengus and blueback herring Alosa aestivalis, even though the habitat is suitable for spawning in the lakes and ponds above the gorge (Fletcher et al. 1982). In contrast, the lowest sections of the Dennys and East Machias rivers do not contain any naturally occurring obstacles to upstream migration and have no abrupt changes in elevation. The significance of Machias's Bad Little Falls is indicated by the virtual absence of anadromous species within this drainage and the presence of these species within the East Machias drainage, which has historically supported a significant alewife fishery (Dubé and Fletcher 1982). This contrast is even more striking, given that the Machias and East Machias drainages share a common estuary/ embayment (Figure 1).

The selective forces of the Bad Little Falls may be one aspect of the functional link responsible for the Machias-specific morphometric patterns documented in this study. The fusiform body coupled with a shortened peduncle region could provide the combination of burst velocities and reduced drag needed to successfully ascend Bad Little Falls (e.g., Riddell and Leggett 1981; Taylor and McPhail 1985b; Hendry and Quinn 1997). Further research on functional morphology is needed to test this hypothesis.

Studies of wild fish in captivity have many advantages over studies in the wild, including greater control of the environment and study organisms. However, cage studies also have limitations, such as (1) logistical constraints, (2) differences between experimental and natural environments, and (3) the consequences of lingering environmental effects. Logistical constraints related to integrating this study into an ongoing partnership between industry and government forced the use of two different freshwater rearing environments. This not only restricted our ability to look at growth across all three populations but also inserted the possibility of alternative conclusions that could explain our results. Given the effect that environmental influences can have on salmonid morphology (Hard et al. 1999; Pakkasmaa and Piironen 2000; Imre et al. 2002) or growth and performance (Solbakken et al. 1994; Nicieza and Metcalfe 1997; Jensen et al. 2000), we cannot rule out the possibility that environmental influences, not genet- 
ics, caused the reported phenotypic variation. However, the weight of evidence suggests there is some genetic component to the differentiation. Additional work is needed that focuses on the impacts of freshwater growth on marine growth and realized morphometrics; moreover, these studies need to be repeated in conditions with minimal differences between populations and their parents at all life history stages. Fortunately, we were able to address more directly the two other potential limitations to cage studies.

The "broad-sense" heritability of growth variation (i.e., phenotypic variation due to genetic effects) can be measured by using a common rearing environment that isolates and minimizes the effects of environmental conditions on growth. Because both genetic and environmental factors control growth of Atlantic salmon in the marine environment (Hansen and Quinn 1998), we reduced environmental effects by rearing different stocks in a common environment. We found no evidence to suggest there was a stock-specific preference with regards to areas of the net-pen. Fish were fed to satiation, which probably minimized aggressive behavior and reduced the effect of dominant/subordinate relationships that could alter growth. Fish within each pen were considered to be a single treatment; therefore, any difference detected between populations, either behavioral or physical, would be driven by genetic differences between populations. In the natural environment, Atlantic salmon postsmolts prefer temperatures between $4^{\circ} \mathrm{C}$ and $8^{\circ} \mathrm{C}$ (Reddin 1985); these thermal conditions were experienced only about one-third of the study rearing time ( $37 \%$ at $\mathrm{CI} ; 32 \%$ at DC). However, the strength of a common garden study lies within the consistency of the environmental influences across all study populations and individuals, not in the mimicking of the natal environment.

When conducting common environment experiments to determine "narrow-sense" heritability (i.e., phenotypic variation due to the additive effects of genes), researchers must take prudent measures to eliminate lingering environmental or maternal effects on phenotypic performance (Conover 1998; Swain and Foote 1999) and to ensure that they are identifying population versus family differences (Taylor 1990). The spatial and temporal aspects of the broodstock collection protocols, their extended hatchery-rearing $(2+$ years $)$ compared with their discrete juvenile freshwater experience ( $<2$ years), the temporal representation in spawning events, and the sampling of embryos from all available crosses should minimize any confounding effects that environmental, maternal, or family influences may have had on the marine growth and morphometrics of these stocks. At a minimum, the results of this experiment demonstrate a significant genetic variation and "broadsense" heritability of growth features (Falconer 1981).

The current study provides the best evidence to date for variation in heritable traits between these endangered populations. However, subsequent investigations should be conducted in a true common garden setting with continued analysis of the F2 generation to assess "narrow-sense" heritability (additive genetic variation). The growth results in the present study were consistent at two marine sites, and our morphometric results show compelling evidence of morphometric differentiation in Machias River Atlantic salmon. We hypothesize that these hydrological characteristics may be an important component of the functional link driving the observed morphometric differences. Local adaptation in terms of morphological differences has been shown to be heritable in salmonids (Riddell et al. 1981; Taylor and McPhail 1985a; Swain and Holtby 1989; Hendry and Quinn 1997; Kinnison et al. 1998). Given these significant phenotypic differences, our study supports the findings of previous researchers who identified genetic differences between these remnant populations (King et al. 2000).

Managers should recognize that enhancement efforts are more likely to succeed if the characteristics of the stocked fish match those favored by natural selection in the local environment (Conover 1998). Given the variety of stock identification tools available, combining results from several techniques may provide valuable insights into the possible stock structure of a species (Begg and Waldman 1999). Combining genetic analysis with morphometrics should lead to a better understanding of both (Winans 1987) and provide a means for successful ecological-genetic population matching (Taylor 1991). As Conover (1998) pointed out, more than genetic data are needed: Geneticists must provide information related to gene flow, population structure, and trait heritability, while fishery biologists and ecologists must provide information on phenotypic variation. Hatcheries must be viewed as both a research laboratory and a production facility. A more comprehensive coordinated survey of the phenotypic variation reflecting local adaptations coupled with the ongoing genetic investigations is needed for all Maine's 
remnant Atlantic salmon populations. Localized variation is an important feature of a population's ability to deal with environmental stresses, and a better understanding of local phenotypic variation is needed to increase the possibility of success of any restoration or conservation effort (Conover 1998; Verspoor 1997).

\section{Acknowledgments}

We acknowledge Atlantic Salmon of Maine, especially David Finlay and Clayton Coffin, and Connors Brothers Aquaculture, especially Dave Morang and Sandy Morrison, for rearing these fish and for supporting our sampling protocols. We also acknowledge the staff from the Maine Atlantic Salmon Commission, the National Marine Fisheries Service, Dave Ouellette, and Gregg Horton for assisting with the sampling for this project. Terence Bradley, Jim Heltshe, Jennifer Specker, Fred Serchuk, Gary Winans, and one anonymous reviewer provided critical advice and patient reviews.

\section{References}

Baum, E. T. 1997. Maine Atlantic salmon: a national treasure. Atlantic Salmon Unlimited. Hermon, Maine.

Baum, E. T., and A. L. Meister. 1971. Fecundity of Atlantic salmon (Salmo salar) from two Maine rivers. Journal of the Fisheries Research Board of Canada 28:764-767.

Begg, G. A., and J. R. Waldman. 1999. An holistic approach to fish stock identification. Fisheries Research 43:35-44.

Bookstein, F. L. 1991. Morphometric tools for landmark data: geometry and biology. Cambridge University Press, Boston.

Burnaby, T. P. 1966. Growth-invariant discriminant functions and generalized distance. Biometrics 22: 96-110.

Cadrin, S. X. 2000. Advances in morphometric identification of fishery stocks. Reviews in Fish Biology and Fisheries 10:91-112.

Carl, L. M., and M. C. Healey. 1984. Differences in enzyme frequency and body morphology among three juvenile life history types of Chinook salmon (Oncorhynchus tshawtscha) in the Nanaimo River, British Columbia. Canadian Journal of Fisheries and Aquatic Sciences 41:1070-1077.

Colligan, M. A., J. F. Kocik, D. C. Kimball, G. Marancik, J. F. McKeon, and P. R. Nickerson. 1999. Status review for anadromous Atlantic salmon in the United States., National Marine Fisheries Service and U.S. Fish and Wildlife Service, Gloucester, Massachusetts.

Conover, D. O. 1998. Local adaptation in marine fishes: evidence and implications for stock enhancement. Bulletin of Marine Science 62:477-493.
Davidson, W. S., T. P. Birt, and J. M. Green. 1989. A review of genetic variation in Atlantic salmon, Salmo salar L., and its importance for stock identification, enhancement programs and aquaculture. Journal of Fish Biology 34:547-560.

Dubé, N. R. and J. S. Fletcher. 1982. The East Machias River: an Atlantic salmon river management report. Pages 39-68 in Machias and East Machias. State of Maine, Atlantic Sea Run Salmon Commission, Bangor.

Falconer, D. S. 1981. Introduction to quantitative genetics. Longmans, London.

FitzGerald, J. L., T. F. Sheehan, and J. F. Kocik. 2004. Visibility of visual implant elastomer tags in Atlantic salmon reared for two years in marine netpens. North American Journal of Fisheries Management 24:222-227.

Flemming, I. A., B. Jonsson, and M. R. Gross. 1994. Phenotypic divergence of sea-ranched, farmed and wild salmon. Canadian Journal of Fisheries and Aquatic Sciences 51:2808-2824.

Fletcher, J. S., R. M. Jordan, and K. F. Beland. 1982. The Machias River: an Atlantic salmon river management report. Pages 1-38 in Machias and East Machias. State of Maine, Atlantic Sea Run Salmon Commission, Bangor.

Hansen, L. P., and T. P. Quinn. 1998. The marine phase of the Atlantic salmon (Salmo salar) life cycle, with comparisons to Pacific salmon. Canadian Journal of Fisheries and Aquatic Sciences 55(Supplement 1): 104-118.

Hard, J. J., G. A. Winans, and J. C. Richardson. 1999. Phenotypic and genetic architecture of juvenile morphometry in Chinook salmon. Journal of Heredity 90(6):597-606.

Hard, J. J., B. A. Berejikian, E. P. Tezak, S. L. Schroder, C. M. Knudsen, and L. T. Parker. 2000. Evidence for morphometric differentiation of wild and captively reared adult coho salmon: a geometric analysis. Environmental Biology of Fishes 58:61-73.

Hendry, A. P., and T. P. Quinn. 1997. Variation in adult life history and morphology among Lake Washington sockeye salmon (Oncorhynchus nerka) populations in relation to habitat features and ancestral affinities. Canadian Journal of Fisheries and Aquatic Sciences 54:75-84.

Ihssen, P. E., H. E. Booke, J. M. Casselman, J. M. McGlade, N. R. Payne, and F. M. Utter. 1981. Stock identification: materials and methods. Canadian Journal of Fisheries and Aquatic Sciences 38:18381855.

Imre, I., R. L. Mclaughlin, and D. L. Noakes. 2002. Phenotypic plasticity in brook charr: changes in caudal fin induced by water flow. Journal of Fish Biology 61(5):1171-1181.

Jensen, A. J., T. Forseth, and B. O. Johnsen. 2000. Latitudinal variation in growth of young brown trout, Salmon trutta. Journal of Animal Ecology 69:10101020 .

Kincaid, H., L. Mengel, and J. Johnson. 1994. Meristic and morphometric evaluation of parr from Atlantic Salmon stocks collected from the Downeast River 
of Maine in 1992-1993. Research and Development Laboratory, National Biological Survey, Preliminary report submitted to the Federal Atlantic Salmon Technical Working Group, Wellsboro, Pennsylvania.

King, T. L., S. T. Kalinowski, W. B. Schill, A. P. Spidle, and B. A. Lubinski. 2001. Population structure of Atlantic salmon (Salmo salar L.): a range-wide perspective from microsatellite DNA variation. Molecular Ecology 10:807-821.

King, T. L., A. P. Spidle, M. S. Eackles, B. A. Lubinski, and W. B. Schill. 2000. Mitochondrial DNA diversity in North American and European Atlantic salmon with emphasis on the Downeast rivers of Maine. Journal of Fish Biology 57:614-630.

Kinnison, M., M. Unwin, N. Boustead, and T. Quinn. 1998. Population-specific variation in body dimensions of adult Chinook salmon (Oncorhynchus tshawytscha) from New Zealand and their source population, 90 years after introduction. Canadian Journal of Fisheries and Aquatic Sciences 55:554563.

MacLean, J. A., and D. O. Evans. 1981. The stock concept, discreteness of fish stocks and fisheries management. Canadian Journal of Fisheries and Aquatic Sciences 38:1889-1898.

MacLean, J. A., D. O. Evans, N. V. Martin, and R. L. Des Jardine. 1981. Survival, growth, spawning distribution, and movements of introduced and native lake trout (Salvelinus namaycush) in two inland Ontario lakes. Canadian Journal of Fisheries and Aquatic Sciences 38:1685-1700.

National Research Council. 2002. Interim report from the Committee on Atlantic salmon in Maine: genetic status of Atlantic salmon in Maine. National Academy Press, Washington, D.C.

Nicieza, A. G., F. G. Reyes-Gavilan, and F. Brana. 1994. Differentiation in juvenile growth and bimodality patterns between northern and southern populations of Atlantic salmon (Salmo salar L.). Canadian Journal of Zoology 72:1603-1610.

Nicieza, A. G., and N. B. Metcalfe. 1997. Growth compensation in juvenile Atlantic salmon: response to depressed temperature and food availability. Ecology 78(8):2385-2400.

Nielsen, J. L. 1998. Population genetics and the conservation and management of Atlantic salmon ( $\mathrm{Sal}$ mo salar). Canadian Journal of Fisheries and Aquatic Sciences 55:145-152.

Nyman, O. L., and J. H. C. Pippy. 1972. Differences in Atlantic salmon, Salmo salar, from North America and Europe. Journal of the Fisheries Research Board of Canada 29:179-185.

Pakkasmaa, S., and J. Piironen. 2000. Water velocity shapes juvenile salmonids. Evolutionary Ecology 14(8):721-730.

Primmer, C. R., P.-A. Landry, E. Ranta, J. Merilae, J. Piironen, K. Tiira, N. Peuhkuri, S. Pakkasmaa, and P. Eskelinen. 2003. Prediction of offspring fitness based on parental genetic diversity in endangered salmonid populations. Journal of Fish Biology 63: 909-927.
Reddin, D. G. 1985. Atlantic salmon (Salmo salar) on and east of the Grand Bank. Journal of the Northwest Atlantic Fishery Science 6:157-164.

Refstie, T., and T. A. Steine. 1978. Selection experiments with salmon III: genetic and environmental sources of variation in length and weight of Atlantic salmon in the freshwater phase. Aquaculture 14: 221-234.

Ricker, W. E. 1972. Heredity and environmental factors affecting certain salmonid populations. Pages 19160 in The stock concept in Pacific salmon. University of British Columbia, Vancouver.

Riddell, B. E., and W. C. Leggett. 1981. Evidence of an adaptive basis for geographic variation in body morphology and time of downstream migration of juvenile Atlantic salmon (Salmo salar). Canadian Journal of Fisheries and Aquatic Sciences 38:308320 .

Riddell, B. E., W. C. Leggett, and R. L. Saunders. 1981. Evidence of adaptive polygenic variation between two populations of Atlantic salmon (Salmo salar) native to tributaries of the S.W. Miramichi River, N.B. Canadian Journal of Fisheries and Aquatic Sciences 38:321-333.

Ritter, J. A. 1975. Lower ocean survival rates for hatchery-reared Atlantic salmon (Salmo salar) stocks released in rivers other than their native streams. International Council for the Exploration of the Sea, C.M. 1975/M: 26, Copenhagen.

Rohlf, J. F. 2001. Morphometrics. State University of New York at Stony Brook, Stony Brook. Available: http://life.bio.sunysb.edu/morph. (August 2001).

Rohlf, F. J., and F. L. Bookstein. 1987. A comment on the shearing method for "size correction". Systematic Zoology 36:356-367.

Rohlf, F. J., and L. F. Marcus. 1983. A revolution in morphometrics. Trends in Ecology and Evolution 8: 129-132.

Saunders, R. L. 1981. Atlantic salmon (Salmo salar) stocks and management implications in the Canadian Atlantic provinces and New England, USA. Canadian Journal of Fisheries and Aquatic Sciences 38:1612-1625.

Schaffer, W. M., and P. F. Elson. 1975. The adaptive significance of variations in life history among local populations of Atlantic salmon in North America. Ecology 56:577-590.

Solbakken, V. A., T. Hansen, and S. O. Stefansson. 1994. Effect of photoperiod and temperature on growth and parr-smolt transformation in Atlantic salmon (Salmo salar L.) and subsequent performance in seawater. Aquaculture 121:13-27.

Strauss, R. E., and F. L. Bookstein. 1982. The truss: body form reconstruction in morphometrics. Systematic Zoology 31:113-135.

Swain, D. P., and C. J. Foote. 1999. Stocks and chameleons: the use of phenotypic variation in stock identification. Fisheries Research 43:113-128.

Swain, D. P., and L. B. Holtby. 1989. Differences in morphology and behavior between juvenile coho salmon (Oncorhynchus kisutch) rearing in a lake and 
in its tributary stream. Canadian Journal of Fisheries and Aquatic Sciences 46:1406-1414.

Tave, D. 1986. Genetics for fish hatchery managers. AVI Publishing, Westport, Connecticut.

Taylor, E. B. 1990. Variability in agonistic behavior and salinity tolerance between and within two populations of juvenile Chinook salmon, Oncorhynchus tshawytscha, with contrasting life histories. Canadian Journal of Fisheries and Aquatic Sciences 47: 2172-2180.

Taylor, E. B. 1991. A review of local adaptation in Salmonidae, with particular reference to Pacific and Atlantic salmon. Aquaculture 98:185-207.

Taylor, E. B., and J. D. McPhail. 1985a. Variation in body morphology among British Columbia populations of coho salmon, Oncorhynchus kisutch. Canadian Journal of Fisheries and Aquatic Sciences 42:2020-2028.

Taylor, E. B., and J. D. McPhail. 1985b. Variation in burst and prolonged swimming performance among British Columbia populations of coho salmon, Oncorhynchus kisutch. Canadian Journal of Fisheries and Aquatic Sciences 42:2029-2033.

Thorpe, J. E., and K. A. Mitchell. 1981. Stocks of Atlantic salmon (Salmo salar) in Britain and Ireland: discreteness and current management. Canadian
Journal of Fisheries and Aquatic Sciences 38:15761590 .

U.S. Atlantic Salmon Assessment Committee. 2002. Annual report of the U.S. Atlantic Salmon Assessment Committee. East Orland, Maine.

Verspoor, E. 1986. Genetic discrimination of European and North American Atlantic salmon using multiple polymorphic protein loci: potential for stock separation in the West Greenland fishery. International Council for the Exploration of the Sea, C.M. 1986/M: 10, Copenhagen.

Verspoor, E. 1997. Genetic diversity among Atlantic salmon (Salmo salar L.) populations. ICES Journal of Marine Science 54:965-973.

Winans, G. A. 1984. Multivariate morphometric variability in Pacific salmon: technical demonstration. Canadian Journal of Fisheries and Aquatic Sciences 41:1150-1159.

Winans, G. A. 1987. Using morphometric and meristic characters for identifying stocks of fish. Pages 2562 in H. E. Kumpf, R. N. Vaught, C. B. Grimes, A. G. Johnston, and E. L. Nakamura, editors. Proceedings of the stock identification workshop, 5-7 November 1985, Panama Beach City, FL. National Oceanic and Atmospheric Administration, Technical Memorandum NMFS-SEFC 199, Washington, D.C. 